\title{
Protective Role of Golden Flaxseed (Linum usitatissimum L.) Against Oxidative Damage in Lipids and Proteins of Healthy Volunteers
}

\author{
Luísa Zuravski'1, Ritiele Pinto Coelho², Jonathaline Apollo Duarte ${ }^{3}$, \\ Manoelly Oliveira Rocha², Juliana Mezzomo', Bruna Cocco Pilar¹, Leandro Leal Galarça², \\ Margareth Linde Athayde ${ }^{4}$, Aline Augusti Boligon ${ }^{4}$, Michel Mansur Machado ${ }^{3}$, \\ Vanusa Manfredini ${ }^{1,2^{*}}$ \\ ${ }^{1}$ Postgraduate Program in Biochemistry, Federal University of Pampa, Uruguaiana, Brazil \\ ${ }^{2}$ Course of Pharmacy, Federal University of Pampa, Uruguaiana, Brazil \\ ${ }^{3}$ Postgraduate Program in Pharmaceutical Sciences, Federal University of Pampa, Uruguaiana, Brazil \\ ${ }^{4}$ Postgraduate Program in Pharmaceutical Sciences, Federal University of Santa Maria, Santa Maria, Brazil \\ Email: ${ }^{*}$ vanusamanfredini@unipampa.edu.br
}

Received 14 August 2015; accepted 9 October 2015; published 12 October 2015

Copyright (C) 2015 by authors and Scientific Research Publishing Inc.

This work is licensed under the Creative Commons Attribution International License (CC BY).

http://creativecommons.org/licenses/by/4.0/

(c) (i) Open Access

\section{Abstract}

Flaxseed (Linum usitatissimum L.) is composed mainly of bioactive components such as polyphenols, polyunsaturated fatty acids, fiber and lignans. Flaxseed can be found in different presentation forms (grain or flour) and varieties (brown or golden); however, questions have arisen as to whether the presentation form and/or variety may influence the health effects. The objective of this study was to evaluate the effects on blood pressure, anthropometric and oxidative parameters in healthy human volunteers. All subjects received 40 gram aliquots of flaxseed and were instructed to consume them in their entirety mixed with water in the morning for a period of 14 days. Oxidative parameters showed significant reductions $(p<0.05)$ in oxidative damage to lipids and proteins via dietary intervention with golden flaxseed grains. There were no significant differences in anthropometric parameters, blood pressure, DNA damage and micronuclei frequency after 14-day supplementation. This research indicates that golden flaxseed grains can be a valuable adjunct for disease prevention and protecting the organism against oxidative damage.

"Corresponding author.

How to cite this paper: Zuravski, L., et al. (2015) Protective Role of Golden Flaxseed (Linum usitatissimum L.) Against Oxidative Damage in Lipids and Proteins of Healthy Volunteers. Journal of Biosciences and Medicines, 3, 45-53.

http://dx.doi.org/10.4236/jbm.2015.310006 


\section{Keywords}

\section{Golden Flaxseed Grains, Antioxidant, Oxidative Damage}

\section{Introduction}

Flaxseed (Linum usitatissimum L.) is a functional food that has been studied extensively because of its antioxidant properties, its ability to lower blood lipid levels, and its potential effects on cardiovascular disease (CVD) risk reduction, mainly due to its high content of polyunsaturated fatty acids (mainly alpha-linolenic acid), soluble fiber and lignans [1]. The major lignan in flaxseed, secoisolariciresinol diglucoside (SDG), has gained significant attention in nutritional and functional food studies due to its substantial biological activities. To our knowledge, no study to date has compared the differences in metabolic effects between the two presentation forms (grain and flour) of brown and golden flaxseed in healthy volunteers. Thus, the aim of this study was to evaluate the effects of 14-day supplementation of flaxseed of different presentations (grain or flour) and varieties (brown or golden) on blood pressure, anthropometric and oxidative parameters.

\section{Materials and Methods}

\subsection{Chemicals}

All reagents were purchased from Sigma Chemical Co. (St. Louis, MO, USA).

\subsection{Plant Material}

Brown and golden flaxseed were obtained from Cerélus Company (Ijuí, State Rio Grande do Sul, Brazil) on February of 2012. Table 1 shows the nutritional information for $40 \mathrm{~g}$ of brown and golden flaxseed, according to the product packaging.

Table 1. Nutritional information of brown and golden flaxseed used in this protocol.

\begin{tabular}{|c|c|c|}
\hline Group/Compound & Brown Flaxseed (in 40 g meal) & Golden Flaxseed (in 40 g meal) \\
\hline Energetic Value (Kcal) & 216.0 & 188.0 \\
\hline Carbohydrates (g) & 12.0 & 13.2 \\
\hline Protein (g) & 10.4 & 8.0 \\
\hline Total Fat (g) & 14.0 & 13.2 \\
\hline Saturated Fat (g) & 0.0 & 1.36 \\
\hline Trans Fat (g) & 0.0 & 0.0 \\
\hline Monounsaturated Fat (g) & 3.2 & 3.2 \\
\hline Polyunsaturated Fat (g) & 8.56 & 8.56 \\
\hline Cholesterol (g) & 0.0 & 0.0 \\
\hline Alimentary Fiber (g) & 5.6 & 10.8 \\
\hline Omega -3 (g) & 7.6 & 6.8 \\
\hline Omega -6 (g) & 2.0 & 2.0 \\
\hline Omega -9 (g) & 2.4 & 3.2 \\
\hline Sodium (mg) & 0.0 & 0.0 \\
\hline Magnesium (mg) & 120.0 & 148.0 \\
\hline Phosphorus (mg) & 280.0 & 200.0 \\
\hline Iron (mg) & 7.2 & 2.40 \\
\hline
\end{tabular}




\subsection{Phytochemical Analysis of Flaxseed (in Vitro)}

Brown and golden flaxseeds were macerated in ethanol-water (70:30 v/v) in the dark and at room temperature for 7 days with daily agitation prior to a phytochemical analysis. Our testes included the determination of total polyphenolic content [2] and the determination of flavonoids [3].

\subsection{Selection of Volunteers}

Sixty non-smoking individuals of both sexes, between the ages of 17 and 34 years, were recruited at Uruguaiana and enrolled in the study between March 2012 and April 2012. Participants had to not have hypertension, not be on regular medication, use no antioxidant or mineral supplementation and have no previous history of stroke, myocardial infarction, angina, diabetes mellitus, cancer or any illness that had required hospitalization during the previous 12 months. Female volunteers were excluded if pregnant, lactating or on hormone replacement therapy. At the end of the study, a total of fifty-four individuals remained.

\subsection{Ethical Issues}

This study, (Protocol N. 069/2011), was approved by CEP of Unipampa. All participants signed a consent form.

\subsection{Experimental Design}

Sixty participants were randomly assigned into one of five independents groups: control group (without supplementation), brown flaxseed (flour or grain) and golden flaxseed (flour or grain) supplementation groups. The control group comprised twelve individuals, who maintained regular diets and received no supplementation. The purpose of this group was to eliminate laboratory abnormalities unrelated to the experimental protocol. The others groups received 40 gram aliquots [4] of their respective forms and varieties of flaxseed for daily use for a period of 14 days [5]. Subjects were instructed to consume the raw flaxseed mixed with water every morning in the experimental period. All groups were instructed to maintain their usual physical activities and food intake.

\subsection{Anthropometric and Pressure Parameters}

At the beginning of the study, all participants had their height measured. The weights were evaluated at the beginning and end of test period. BMI was calculated using the equation BMI $=$ weight $(\mathrm{kg}) / \mathrm{height}^{2}\left(\mathrm{~m}^{2}\right)$. Blood pressure was checked from the right arm with the participant seated, after a 4 - 5 minutes rest by a person trained to carry out the process in a reproducible way. We use a digital manometer to perform these measures.

\subsection{Blood Sample Collection}

Fasting blood samples were taken at day "0" and day "14", always between 7:00 and 9:00 a.m. Blood was drawn from the antecubital vein into prechilled tubes containing EDTA and Li-heparin and tubes without anticoagulant (Vacutainer-Becton, Dickinson and Company. Trenton, NJ, USA). The blood in tubes without anticoagulant stays at room temperature for 30 minutes to clot. The plasma and serum were obtained after centrifugation of blood samples at $1500 \times \mathrm{g}$ for $10 \mathrm{~min}$ and analyzed immediately.

\subsection{Analysis of Oxidative Parameters}

The oxidative parameters such as lipid peroxidation [6] and carbonyl protein content [7] were measured in plasma using spectrophotometric methods. The assessment of DNA damage was made by comet assay [8] and frequency of micronuclei [9] in leukocytes of whole blood. The activities of catalase [10], superoxide dismutase (kit RANSOD-RANDOX Brasil LTDA, Belo Horizonte, MG, Brazil) and glutathione peroxidase (kit RANSEL -RANDOX Brasil LTDA, Belo Horizonte, MG, Brazil) were measured in erythrocytes.

\subsection{Statistical Analysis}

Data were expressed as mean \pm standard deviation (SD). Comparisons between groups were performed using a two-way analysis of variance (ANOVA), followed by a post-hoc Bonferroni for multiple comparison tests. Results were considered statistically significant when $p<0.05$. 


\section{Results}

\subsection{Phytochemical Analysis}

Table 2 shows the polyphenols and flavonoids present in the flaxseed. Brown flaxseed presented a slightly higher polyphenol level than golden flaxseed and there was no difference between flour and grains. However, the amount of flavonoid was 2.6 times higher in brown flaxseed grains than brown flour and 1.5 times higher in golden grains than golden flour.

\subsection{Anthropometric Parameters and Blood Pressure}

Table 3 shows the anthropometric parameters and blood pressure of the volunteers on days 0 and 14 . There were no significant differences $(p<0.05)$ in these parameters during the study period.

\subsection{Oxidative Parameters}

Figure 1 shows the results of biomarkers of oxidative damage, before (day 0 ) and after 14 days of supplementation (day 14). There were no significant changes in oxidative parameters in the control group during the trial period. The ingestion of brown or golden flaxseed grain over 14 days caused a reduction of lipid peroxidation in the or-

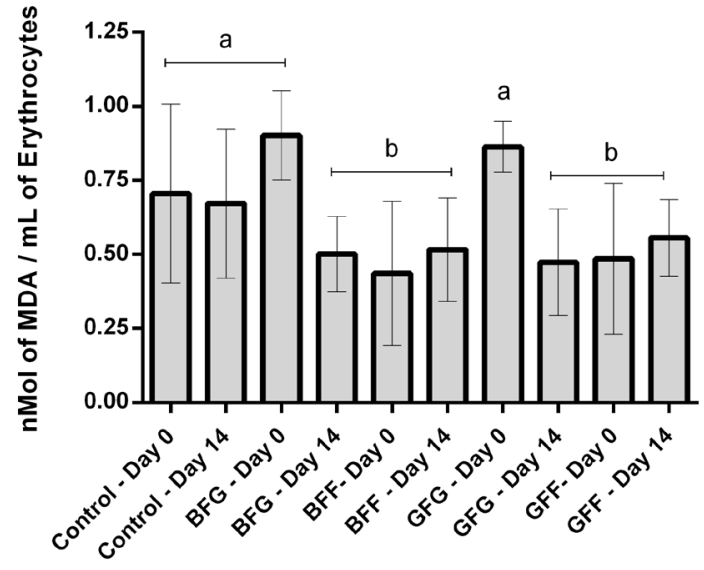

(a)

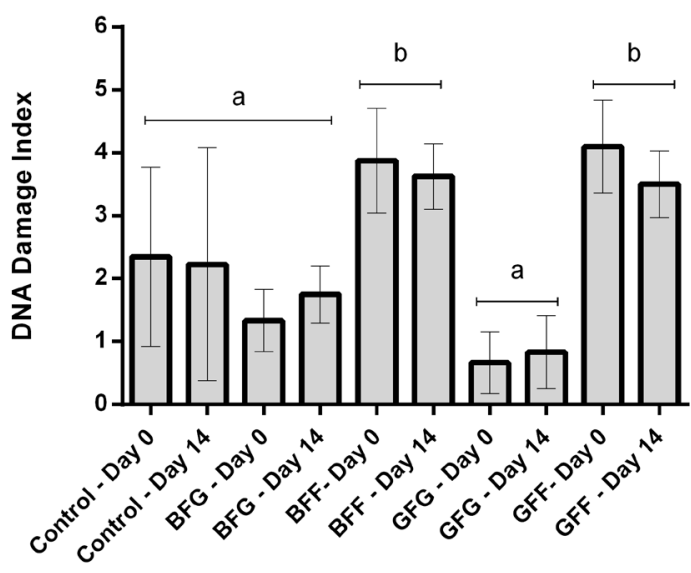

(c)

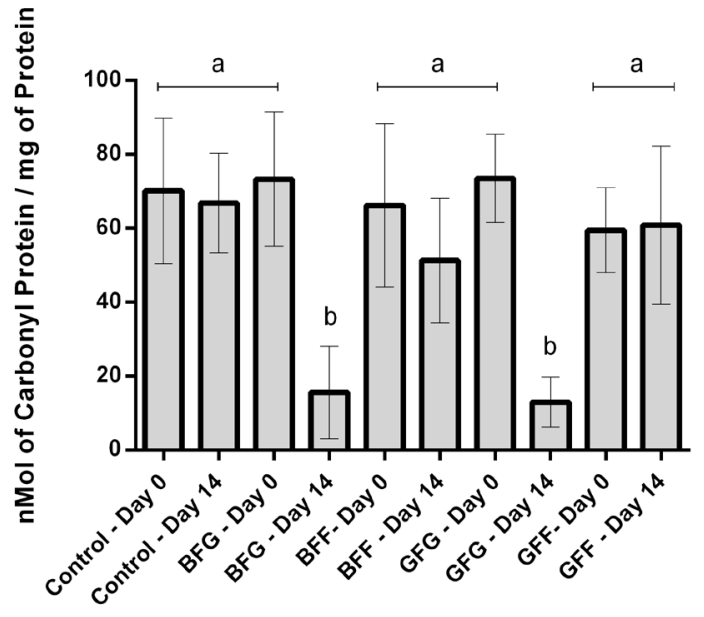

(b)

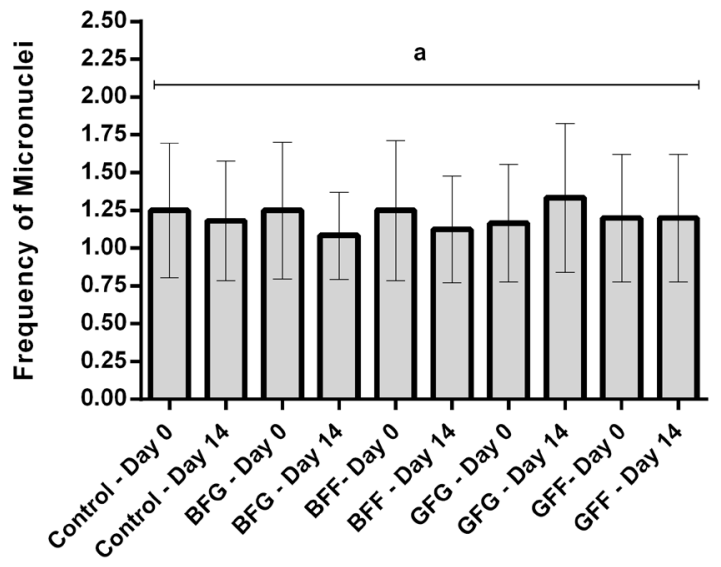

(d)

Figure 1. Oxidative damage markers in healthy volunteers in trial period. In (a) lipid peroxidation levels; (b) carbonyl protein contents; (c) DNA damage index; (d) frequency of micronuclei. Data are expressed as means \pm S.D. Different letters means statistically different results. Legend: BFG: Brown Flaxseed Grain; BFF: Brown Flaxseed Flour; GFG: Golden Flaxseed Grain; GFF: Golden Flaxseed Flour. 
Table 2. Phytochemical analysis of brown and golden flaxseed used in this protocol.

\begin{tabular}{|c|c|c|c|c|}
\hline Group & Brown Flaxseed Flour ${ }^{*}$ & Brown Flaxseed Grain ${ }^{*}$ & Golden Flaxseed Flour ${ }^{*}$ & Golden Flaxseed Grain \\
\hline Polyphenol & $15970 \pm 912$ & $15940 \pm 863$ & $10550 \pm 749$ & $10560 \pm 839$ \\
\hline Total flavonoids & $5050 \pm 434$ & $13360 \pm 748$ & $6234 \pm 673$ & $9740 \pm 642$ \\
\hline
\end{tabular}

* In $\mu g / g$ of flaxseed. Data from the preparations are expressed as means \pm S.D $(n=3)$.

Table 3. Anthropometric and pressure parameters of the volunteers in trial period.

\begin{tabular}{|c|c|c|c|c|c|c|c|c|c|c|}
\hline \multirow{2}{*}{ Parameters } & \multicolumn{2}{|c|}{ Control Group } & \multicolumn{2}{|c|}{ Brown Flaxseed Flour } & \multicolumn{2}{|c|}{ Brown Flaxseed Grain } & \multicolumn{2}{|c|}{ Golden Flaxseed Flour } & \multicolumn{2}{|c|}{ Golden Flaxseed Grain } \\
\hline & Day 0 & Day 14 & Day 0 & Day 14 & Day 0 & Day 14 & Day 0 & Day 14 & Day 0 & Day 14 \\
\hline $\begin{array}{c}\text { Total } \\
\text { Volunteers }\end{array}$ & \multicolumn{2}{|c|}{12 volunteers } & \multicolumn{2}{|c|}{8 volunteers } & \multicolumn{2}{|c|}{12 volunteers } & \multicolumn{2}{|c|}{10 volunteers } & \multicolumn{2}{|c|}{12 volunteers } \\
\hline $\begin{array}{c}\text { Male } \\
\text { Volunteers }\end{array}$ & \multicolumn{2}{|c|}{7} & \multicolumn{2}{|c|}{3} & \multicolumn{2}{|c|}{6} & \multicolumn{2}{|r|}{4} & \multicolumn{2}{|r|}{5} \\
\hline $\begin{array}{c}\text { Female } \\
\text { Volunteers }\end{array}$ & \multicolumn{2}{|c|}{5} & \multicolumn{2}{|c|}{5} & \multicolumn{2}{|c|}{6} & \multicolumn{2}{|r|}{6} & \multicolumn{2}{|r|}{7} \\
\hline $\begin{array}{l}\text { Medium Age } \\
\text { (in Years) }\end{array}$ & \multicolumn{2}{|c|}{$\begin{array}{c}23 \text { years } \\
(17-32 \text { years })\end{array}$} & \multicolumn{2}{|c|}{$\begin{array}{c}24 \text { years } \\
\text { (17 - } 33 \text { years) }\end{array}$} & \multicolumn{2}{|c|}{$\begin{array}{c}23 \text { years } \\
(18-32 \text { years })\end{array}$} & \multicolumn{2}{|c|}{$\begin{array}{c}23 \text { years } \\
(17-34 \text { years })\end{array}$} & \multicolumn{2}{|c|}{$\begin{array}{c}26 \text { years } \\
\text { (18 - } 33 \text { years) }\end{array}$} \\
\hline $\begin{array}{c}\text { Body Mass } \\
\text { Index } \\
\left(\mathrm{BMI}, \mathrm{in} \mathrm{Kg} / \mathrm{m}^{2}\right)\end{array}$ & $23.74 \pm 4.00$ & $23.26 \pm 4.35$ & $23.09 \pm 2.33$ & $23.16 \pm 2.21$ & $24.39 \pm 5.67$ & $24.27 \pm 5.46$ & $22.89 \pm 4.54$ & $23.06 \pm 4.49$ & $23.62 \pm 4.15$ & $23.58 \pm 4.07$ \\
\hline $\begin{array}{c}\text { Systolic } \\
\text { Pressure } \\
\text { (in mmHg) }\end{array}$ & $129.00 \pm 15.81$ & $126.05 \pm 10.73$ & $131.3 \pm 17.27$ & $121.3 \pm 15.53$ & $126.7 \pm 14.35$ & $115.8 \pm 10.84$ & $128.8 \pm 9.91$ & $126.0 \pm 11.74$ & $123.3 \pm 1.55$ & $114.2 \pm 15.64$ \\
\hline $\begin{array}{l}\text { Diastolic } \\
\text { Pressure } \\
\text { (in mmHg) }\end{array}$ & $84.17 \pm 11.81$ & $80.97 \pm 8.74$ & $85.00 \pm 13.78$ & $81.26 \pm 11.26$ & $83.33 \pm 9.84$ & $74.17 \pm 7.93$ & $84.44 \pm 8.81$ & $83.33 \pm 10.00$ & $77.50 \pm 8.66$ & $69.17 \pm 7.93$ \\
\hline
\end{tabular}

Data are expressed as means \pm S.D. In all parameter evaluated, there were no statistically different results in the column.

der of $44.37 \% \pm 16.6 \%$ and $54.88 \% \pm 20.8 \%$ respectively. Similar result was not observed in the ingestion of brown or golden flaxseed flour (Figure 1(a)). In Figure 1(b) significant reductions $(p<0.05)$ in protein carbonyl levels can be seen. Figure 1(c) and Figure 1(d) show the results of the comet assay and micronuclei test, respectively. There were no significant changes $(p<0.05)$ in these two tests which both assess genetic damage. Figures 2(a)-(c) show the activity of superoxide dismutase (SOD), catalase (CAT) and glutathione peroxidase (GPx), respectively. These enzymatic parameters showed no alterations.

\section{Discussion}

Epidemiologic and clinical evidence supports the beneficial effect of flaxseed consumption in adult individuals. To our knowledge, no study to date has compared the presentation forms (grain or flour) while examining the metabolic effects of the intake of brown and golden flaxseed in healthy volunteers. In this study, the participants' blood pressure and BMI were within the normal range for healthy people, according to Stahl et al. [11]. No significant differences were observed in these parameters during the study period. These findings are consistent with studies by Stuglin and Prasad [12] who found no significant differences in blood pressure during a 4-week intervention using $32.7 \mathrm{~g} /$ day of flaxseed.

Oxidative stress is a condition resulting from an imbalance between production and inactivation of reactive oxygen species (ROS) and it plays an important role in the pathogenesis of several diseases [13]. ROS attack unsaturated fatty acids in biological membranes, resulting in lipid peroxidation as well as desaturation of proteins and DNA. Many functional foods have been studied for their capacity to reduce the oxidative damage and flaxseed has been shown to produce antioxidant effects in human and animal model studies [5] [14].

Lipid peroxidation is a complex process that involves the interaction of ROS with polyunsaturated fatty acids of cell membranes, resulting in the formation of hydro or lipoperoxides, which are highly reactive and can initiate an oxidative cascade, with severe damage to the integrity of the membrane [15]. The decrease in MDA levels after flaxseed supplementation demonstrates a reduction in lipid peroxidation in both GFG and BFG groups. 


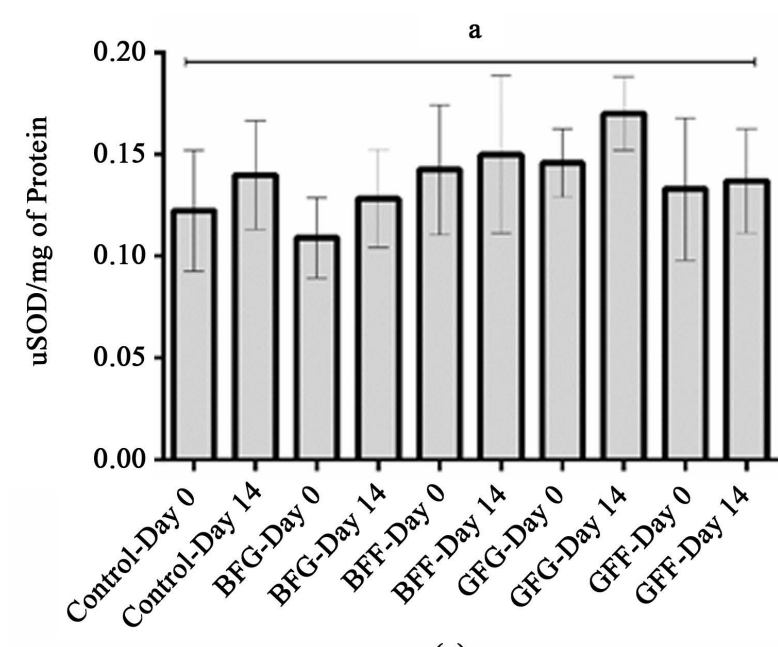

(a)

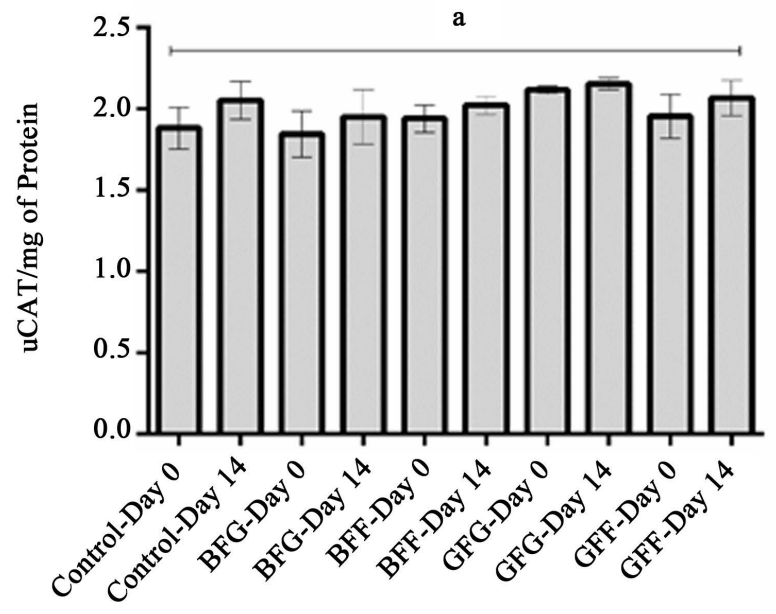

(b)

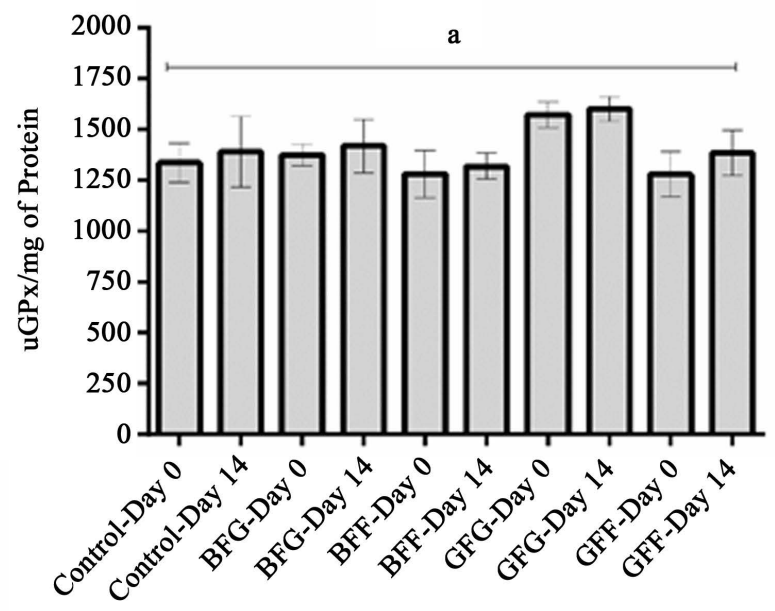

(c)

Figure 2. Oxidative defenses markers in healthy volunteers in trial period. In (a) superoxide dismutase activity; (b) catalase activity; (c) glutathione peroxidase activity. Data are expressed as means \pm S.D. Different letters means statistically different results. Legend: BFG: Brown Flaxseed Grain; BFF: Brown Flaxseed Flour; GFG: Golden Flaxseed Grain; GFF: Golden Flaxseed Flour. 
In agreement with these findings, a study by Prasad [16] demonstrated a reduction in serum MDA levels in hypercholesterolemic rabbits after treatment with a flax lignan complex isolated from flaxseed, suggesting that these substances are responsible for the observed effects. Furthermore, one type of flaxseed lignan, SDG, exhibited antioxidant activity by either direct radical scavenging or by inhibition of lipid peroxidation [17]. In our study, the results are probably related to the greater amounts of flavonoids (Table 2) and polyunsaturated fatty acids (PUFA), found in the flaxseed grains, suggesting that these compounds are responsible for the reduction in lipid peroxidation. It has been well established that flaxseeds containing PUFA are highly susceptible to oxidative deterioration. This oxidative deterioration results in decreased nutritional quality. Thus, the absence of effects on supplementation with flaxseed flour could be related to the oxidative deterioration of biological compounds due to processing and to the flour's low flavonoid content [18] [19].

The oxidative modifications of proteins caused by ROS primarily affect amino acid side chains and carbonyl group formation is one product of these modifications [20]. The results of this study, show a decrease in protein carbonyl levels after supplementation with flaxseed grains, indicating a reduction in oxidative protein changes. However, this effect was not observed with the use of flaxseed flour. Chang et al. [21] demonstrated a reduction in protein carbonyl levels after dietary intervention with a high content of polyphenols, suggesting that they are responsible for protection against oxidative damage to proteins. As previously mentioned, the PUFA content and greater amounts of flavonoids found in flaxseed grains suggest that these compounds are responsible for the reduction in protein carbonyl levels observed in this study.

In addition to lipid and protein oxidation, reactive species can also cause DNA damage. The impacts include damage and fragmentation of the DNA bases and, if not repaired, may lead to chromosomal mutations that disrupt the normal gene expression and create abnormal proteins that are detrimental to cell viability and cellular function [22]. Another biomarker for DNA damage widely used in humans because of its simplicity and rapidity is a measure of the micronuclei frequency in human peripheral blood leucocytes [23]. In this study, the comet assay and micronuclei frequency were used to assess DNA damage in healthy individuals and to evaluate the possible role of flaxseed in reversing or preventing this damage. All groups exhibited normal values in these two tests during the trial period, demonstrating that flaxseed is not able to produce cytogenetic changes. These findings are consistent with the studies of Bub et al. [24] who found no changes in DNA damage after 14 days of consumption of polyphenol-rich beverages.

Studies have shown that diets rich in antioxidants can protect against oxidative damage to lipids, proteins and nucleic acids [25]. Flaxseed has a high concentration of polyphenols (especially lignans). Polyphenols are secondary metabolites of plants and constitute the largest group of natural antioxidants (Ciesla, Kowalska, Oleszek, \& Stochmal, 2012; Hu et al., 2011). Regular consumption of foods rich in polyphenols can increase the potential of antioxidant defense against oxidative damage and prevent oxidation of lipids and proteins by neutralizing certain free radicals [21].

Humans have several antioxidant defense systems that all operate differently in the detoxification of reactive species. Among them, the antioxidant enzyme system appears to be the main way of removing reactive species formed during intracellular metabolism [26]. The activity of antioxidant enzymes SOD, CAT and GPx did not change significantly after 14 days of supplementation with flaxseed of both varieties and forms of presentation. This enzymatic profile is probably related to the time period of the protocol, since other studies involving antioxidant enzymes usually observed positive correlations during 30 days of intervention with polyphenol-rich meals [27].

In conclusion, this study showed that golden flaxseed grains are more effective in reducing oxidative parameters even in a short supplementation period.

\section{Conclusion}

The results indicate that markers of oxidative damage such as lipid peroxidation and carbonyl protein content dropped significantly with supplementation of golden flaxseed grains. Therefore, even a short supplementation period ( 2 weeks) with golden flaxseed grains can be an important cofactor in the prevention of diseases that are based on the production of free radicals.

\section{References}

[1] Goyal, A., Sharma, V., Upadhyay, N., Gill, S. and Sihag, M. (2014) Flax and Flaxseed Oil: An Ancient Medicine \& Modern Functional Food. Journal of Food Science and Technology, 51, 1633-1653. 
[2] Chandra, S. and De Mejia Gonzalez, E. (2004) Polyphenolic Compounds, Antioxidant Capacity, and Quinone Reductase Activity of an Aqueous Extract of Ardisia compressa in Comparison to Mate (Ilex paraguariensis) and Green (Camellia sinensis) Teas. Journal of Agricultural and Food Chemistry, 52, 3583-3589. http://dx.doi.org/10.1021/jf0352632

[3] Woisky, R.G. and Salatino, A. (1998) Analysis of Propolis: Some Parameters and Procedures for Chemical Quality Control. Journal of Apicultural Research, 37, 99-105.

[4] Bloedon, L.T., Balikai, S., Chittams, J., Cunnane, S.C., Berlin, J.A., Rader, D.J., et al. (2008) Flaxseed and Cardiovascular Risk Factors: Results from a Double Blind, Randomized, Controlled Clinical Trial. Journal of the American College of Nutrition, 27, 65-74. http://dx.doi.org/10.1080/07315724.2008.10719676

[5] Rajesha, J., Murthy, K.N., Kumar, M.K., Madhusudhan, B. and Ravishankar, G.A. (2006) Antioxidant Potentials of Flaxseed by in Vivo Model. Journal of Agricultural and Food Chemistry, 54, 3794-3799. http://dx.doi.org/10.1021/jf053048a

[6] Ohkawa, H., Ohishi, N. and Yagi, K. (1979) Assay for Lipid Peroxides in Animal Tissues by Thiobarbituric Acid Reaction. Analytical Biochemistry, 95, 351-358. http://dx.doi.org/10.1016/0003-2697(79)90738-3

[7] Levine, R., Garland, D., Oliver, C., Amici, A., Climent, I., Lenz, A., et al. (1990) Damage to Proteins and Lipids Tissues under Oxidative Stress. Methods in Enzymology, 186, 464-478. http://dx.doi.org/10.1016/0076-6879(90)86141-H

[8] Singh, N.P., McCoy, M.T., Tice, R.R. and Schneider, E.L. (1988) A Simple Technique for Quantitation of Low Levels of DNA Damage in Individual Cells. Experimental Cell Research, 175, 184-191. http://dx.doi.org/10.1016/0014-4827(88)90265-0

[9] Schmid, W. (1975) The Micronucleus Test. Mutation Research, 31, 9-15. http://dx.doi.org/10.1016/0165-1161(75)90058-8

[10] Aebi, H. (1984) Catalase in Vitro. Methods in Enzymology, 105, 121-126. http://dx.doi.org/10.1016/S0076-6879(84)05016-3

[11] Stahl, C.H., Novak, M., Lappas, G., Wilhelmsen, L., Bjorck, L., Hansson, P.O., et al. (2012) High-Normal Blood Pressure and Long-Term Risk of Type 2 Diabetes: 35-Year Prospective Population Based Cohort Study of Men. BMC Cardiovascular Disorders, 12, 89. http://dx.doi.org/10.1186/1471-2261-12-89

[12] Stuglin, C. and Prasad, K. (2005) Effect of Flaxseed Consumption on Blood Pressure, Serum Lipids, Hemopoietic System and Liver and Kidney Enzymes in Healthy Humans. Journal of Cardiovascular Pharmacology and Therapeutics, 10, 23-27. http://dx.doi.org/10.1177/107424840501000103

[13] Furukawa, S., Fujita, T., Shimabukuro, M., Iwaki, M., Yamada, Y., Nakajima, Y., et al. (2004) Increased Oxidative Stress in Obesity and Its Impact on Metabolic Syndrome. Journal of Clinical Investigation, 114, 1752-1761. http://dx.doi.org/10.1172/JCI21625

[14] Rhee, Y. and Brunt, A. (2011) Flaxseed Supplementation Improved Insulin Resistance in Obese Glucose Intolerant People: A Randomized Crossover Design. Nutrition Journal, 10, 44. http://dx.doi.org/10.1186/1475-2891-10-44

[15] Tsang, A.H.K. and Chung, K.K.K. (2009) Oxidative and Nitrosative Stress in Parkinson's Disease. Biochimica et Biophysica Acta (BBA)-Molecular Basis of Disease, 1792, 643-650.

[16] Prasad, K. (2005) Hypocholesterolemic and Antiatherosclerotic Effect of Flax Lignan Complex Isolated from Flaxseed. Atherosclerosis, 179, 269-275. http://dx.doi.org/10.1016/j.atherosclerosis.2004.11.012

[17] Kasote, D. (2013) Flaxseed Phenolics as Natural Antioxidants. International Food Research Journal, 20, 27-34.

[18] Aladedunye, F., Sosinska, E. and Przybylski, R. (2013) Flaxseed Cyclolinopeptides: Analysis and Storage Stability. Journal of the American Oil Chemists' Society, 90, 419-428. http://dx.doi.org/10.1007/s11746-012-2173-0

[19] Abuzaytoun, R. and Shahidi, F. (2006) Oxidative Stability of Flax and Hemp Oils. Journal of the American Oil Chemists' Society, 83, 855-861. http://dx.doi.org/10.1007/s11746-006-5037-7

[20] Tamarit, J., de Hoogh, A., Obis, E., Alsina, D., Cabiscol, E. and Ros, J. (2012) Analysis of Oxidative Stress-Induced Protein Carbonylation Using Fluorescent Hydrazides. Journal of Proteomics, 75, 3778-3788. http://dx.doi.org/10.1016/j.jprot.2012.04.046

[21] Chang, W.-H., Hu, S.-P., Huang, Y.-F., Yeh, T.-S. and Liu, J.-F. (2010) Effect of Purple Sweet Potato Leaves Consumption on Exercise-Induced Oxidative Stress and IL-6 and HSP72 Levels. Journal of Applied Physiology, 109, 1710-1715. http://dx.doi.org/10.1152/japplphysiol.00205.2010

[22] Furness, D.L.F., Dekker, G.A. and Roberts, C.T. (2011) DNA Damage and Health in Pregnancy. Journal of Reproductive Immunology, 89, 153-162. http://dx.doi.org/10.1016/j.jri.2011.02.004

[23] Frieauff, W., Martus, H.J., Suter, W. and Elhajouji, A. (2013) Automatic Analysis of the Micronucleus Test in Primary Human Lymphocytes Using Image Analysis. Mutagenesis, 28, 15-24. http://dx.doi.org/10.1093/mutage/ges047 
[24] Bub, A., Watzl, B., Blockhaus, M., Briviba, K., Liegibel, U., Müller, H., et al. (2003) Fruit Juice Consumption Modulates Antioxidative Status, Immune Status and DNA Damage. The Journal of Nutritional Biochemistry, 14, 90-98. http://dx.doi.org/10.1016/S0955-2863(02)00255-3

[25] Katz, D.L., Doughty, K. and Ali, A. (2011) Cocoa and Chocolate in Human Health and Disease. Antioxidants \& Redox Signaling, 15, 2779-2811. http://dx.doi.org/10.1089/ars.2010.3697

[26] Yuan, Y.V., Rickard, S.E. and Thompson, L.U. (1999) Short-Term Feeding of Flaxseed or Its Lignan Has Minor Influence on in Vivo Hepatic Antioxidant Status in Young Rats. Nutrition Research, 19, 1233-1243. http://dx.doi.org/10.1016/S0271-5317(99)00084-6

[27] Nelson, S.K., Bose, S.K., Grunwald, G.K., Myhill, P. and McCord, J.M. (2006) The Induction of Human Superoxide Dismutase and Catalase in Vivo: A Fundamentally New Approach to Antioxidant Therapy. Free Radical Biology \& Medicine, 40, 341-347. http://dx.doi.org/10.1016/j.freeradbiomed.2005.08.043 